\title{
Peranan Pendidikan Teologia Bagi Seorang Gembala Jemaat
}

\author{
Luhut El Roy Manalu, ${ }^{1} *$ Mitra Binariang Lase, ${ }^{2}$ Agiana Her Visnhu Ditakristi ${ }^{3}$ \\ Prodi PAK, STT Real Batam \\ Prodi PAK, STT Real Batam \\ Prodi PAK, STT Real Batam \\ elroy_btm@yahoo.com
}

\begin{abstract}
The progress of science and technology today has occupied all lines with their respective backgrounds in the field of tasks they are involved in, even the awampun have accidentally become knowledgeable and skilled in other fields that are not fields of knowledge whose expertise, including in theology. It could even be that before the Shepherd preached, the congregation had already understood what was conveyed by the Pastor. Besides that with the rapid world of Education, many members of the congregation have received a higher education than their pastor, this is a challenge for the pastor of the church, in the delivery of God's Word in the church must meet the needs of all congregations not only for lay people but also clever clever also a member of the congregation. Based on the things mentioned above, a Pastor is inevitably required to have formal education in this case theology, so that through theological education a pastor is more capable of conveying the truth of God's Word. Not only that, a pastor who has a Theological Education can more easily ward off the wrong teachings that are developing in this area.
\end{abstract}

Keywords: Education, Theology, Pastor, Congregation

\begin{abstract}
Abstrak
Kemajuan ilmu pengetahuan dan tekhnologi dewasa ini telah menempati semua lini dengan masing-masing latar belakang bidang tugas yang digelutinya, bahkan kaum awampun secara tidak sengaja telah menjadi tahu dan trampil dibidang lain yang bukan bidang pengetahuan yang keahliannya, termasuk dibidang Teologi. Bahkan bisa saja sebelum Gembala berkotbah maka jemaat sudah lebih dahulu memahami apa yang disampaikan oleh Gembala jemaat. Disamping itu dengan pesatnya dunia Pendidikan maka banyak diantara warga jemaat sudah mengenyam Pendidikan yang lebih tinggi dari gembalanya, ini merupakan suatu tantangan bagi gembala jemaat, dalam penyampaian Firman Tuhan dalam gereja harus memenuhi kebutuhan semua jemaat tidak hanya bagi kaum awam tetapi juga para cerdik pandai yang juga merupakan warga jemaat. Berdasarkan hal-hal tersebut diatas maka seorang Gembala jemaat mau tidak mau dituntut untuk memiliki Pendidikan formal dalam hal ini Teologi, sehingga melalui Pendidikan Teologi seorang gembala lebih teramapil dalam menyampaikan Kebenaran Firman Tuhan. Tidak hanya itu, seorang gembala yang memiliki Pendidikan Teologia dapat lebih mudah menangkal ajaran-ajaran yang salah yang sedang berkembang diera ini.
\end{abstract}

Kata kunci: Pendidikan, Teologi, Gembala, Jemaat

\section{PENDAHULUAN}

Sering kali kita dengar ada banyak pejabat yang dalam sambutannya menggunakan ayat-ayat Alkitab atau ilustrasi dari Alkitab dan juga menafsir isi Alkitab dalam meneguhkan sambutannya. Ini merupakan tantangan bagi seorang Hamba Tuhan terutama 
Gembala Sidang bahwa ia sedang berada ditengah-tengah orang yang sudah banyak tahu tentang seluk beluk pelayanan ataupun ajaran theologia sehingga menuntut seorang Gembala harus memiliki pemahaman dan pengetahuan Firman Allah yang makin dalam dan memiliki pengetahuan Teologia yang memadai sehingga dapat menjadi pemimpin ditengah-tengah jemaat yang semakin pintar.

Gereja harus menjadi lembaga yang terpimpin yang terus menerus bertransformasi, termasuk dalam hal teologi. Baik secar kualitas maupun kuantitas. Ada banyak isu yang menjadi rahasia umum dimana Gereja berhenti bertumbuh pada titik tertentu, karena tidak mengembangkan kepemimpinan yang cakap dan cukup untuk melayani anggota-anggota baru. ${ }^{1}$

Seorang Gembala sidang dituntut harus memiliki pengetahuan yang melebihi pengetahuan jemaat maupun harus dapat mengarahkan, mengajar serta meyakinkan jemaat bahwa gembalanya memiliki pengetahuan yang memadai dan mampu menjawab tantangan serta bila dibandingkan dengan pendeta lainnya, Gembalanya tidak kalah ataupun berada pada tingkatan yang tidak diragukan. Untuk menjawab tuntutan ini maka seorang Gembala Sidang tidak hanya cukup dengan berdoa dan membaca Firman Allah tapi harus mampu menyesuaikan dan mengimbangi perkembangan zaman dengan menguasai berita-berita yang kontemporer terutama tentunya dalam bidang Teologia.

Selain tugas gembala yang mampu merawat dan menyembuhkan domba juga gembala dituntut harus mampu memberi makanan yang segar, bergizi dan lezat bagi makanan domba. Maksudnya seorang gembala dituntut dapat menjawab tantangan dan harapan jemaat dan juga gembala harus dipacu mengejar ketertinggalan, mampu menyesuaikan dengan perkembangan dan bukan hanya menjadi follower tetapi harus menjadi settertrendy atau menjadi innovator.

Menurut Frederic Greeves dalam buku Teologi Penggembalaan menuliskan bahwa "Semua manusia baik sebagai domba maupun sebagai gembala membutuhkan doktrin Kristen dalam tingkat daripada yang diakui sekarang ini" ${ }^{2}$ artinya yang lebih luas, untuk maksud tersebut diatas maka jawabannya hanya ditemukan pada pendidikan teologia secara systematis, mendasar, berjenjang dan lengkap. Hal ini bukan hanya ditimba dari Sekolah Alkitab yang 9 bulan atau SOM yang tiga bulan tetapi harus melalui pendidikan yang kualitasnya sesuai. Dapat dipastikan kriteria seorang Gembala harus mencapai sebuah pendidikan yang minimal jenjang S1 dalam peletakan dasar pengetahuan Teologia sehingga baik khotbahnya bernuansa teologia yang terkini dan kaya dalam pembahasan ilmiah teologis dengan variasi yang menyegarkan bukan membosankan dengan pendekatan ilmu yang semakin inspiratif bukan meniru, menjiplak atau menyontek tapi makin dinamis, produktif dan tepat sasaran.

\footnotetext{
${ }^{1}$ Fredy Simanjuntak, "Kecerdasan Emosi Pemimpin Sebagai Tolok Ukur Gereja Yang Sehat,” Real Didache 2, no. 1 (2017): 29-53.

${ }^{2}$ Derek J Tidball, Teologi Penggembalaan Sebuah Pengantar (Malang: Gandum Mas, 1986).32
} 
Bukan sedikit Gembala yang tidak punya pengetahuan mengomentari sesama gembala dengan kacamata pengetahuan yang orthodoks dan non teologis namun menggunakan istilah teologia yang tidak dimengerti ketika ia mau merendahkan hamba Tuhan yang dianggap kurang berpendidikan sedangkan bagi yang berpendidikan dituduh terlalu menggunakan otak dan kurang berdoa dan lain-lain, padahal dia sendiri kurang berbobot. Pelayanan dalam homilitika, hermeneutika dan bahasa aslinya sangat kurang menjadi alasan untuk menuduh yang mengikuti pendidikan theologia tercela. Sering alasan waktu, usia, dan kesibukan dalam pelayanan dijadikan alasan untuk tidak dapat meningkatkan pengetahuan teologia sehingga performance seorang gembala diukur kurang berbobot.

\section{METODE}

Adapun metode yang dipakai dalam penelitian ini adalah pendekatan kualitatif deskriptif yang bertujuan untuk mengambarkan secara sistematis mengenai peranan pendidikan teologi bagi seorang gembala sidang dengan didukung berbagai literarut baik berupa jurnal, buku dan karya ilmiah.

\section{HASIL DAN PEMBAHASAN}

\section{Peranan Pendidikan Teologia Gembala}

Peran berarti : 1. Pemain sandiwara (Film); 2. Perangkat tingkah yang diharapkan dimiliki oleh seseorang yang berkedudukan dimasyarakat. Dari kata "Peran" terbentuk kata "Peranan" setelah ditambah imbuhan yang berupa akhiran "an" yang berarti : Bagian yang dimainkan oleh seseorang dalam suatu peristiwa. ${ }^{3}$ Kata peran diambil dari istilah teater dan merupakan bagian yang tidak terpisahkan dari kelompok-kelompok masyarakat. Peran adalah bagian yang kita mainkan pada setiap keadaan dan mengandung cara bertingkah laku dalam menyelaraskan diri dengan keadaan. Peran ditentukan oleh kondisi subyektif seseorang. Artinya semakin banyak peran yang dimiliki oleh seseorang, maka semakin besar pula kemungkinan yang diperolehnya untuk meraih kesuksesan.

Suatu peran paling sedikit mencakup dua hal yaitu : Pertama peran meliputi norma-norma yang dihubungkan dengan posisi atau tempat seseorang dalam masyarakat; Kedua peran adalah konsep perihal yang dilakukan oleh individu dalam masyarakat sehingga peran dapat pula dikatakan sebagai perilaku dalam struktur masyarakat.

Peran juga adalah perilaku yang diharapkan dari seseorang yang mempunyai suatu status.

\footnotetext{
${ }^{3}$ Hasan Alwi, Kamus Besar Bahasa Indonesia (Jakarta: Balai Pustaka, 2005).854
} 


\section{Pendidikan}

Pendidikan dapat dikatakan sebagai upaya dasar dan bersahaja untuk melengkapi seseorang atau sekelompok orang, membimbing keluar dari satu keadaan hidup ke suatu tahapan lainnya yang lebih baik.

Dalam pengertian umum Suwarno mengemukakan Paedagogie yang berarti pendidikan, yang berhubungan dengan tindakan mendidik, sedangkan paedagogiek berarti ilmu pendidikan yang mengutamakan perenungan ilmiah. ${ }^{4}$

Jadi pendidikan itu merupakan tindakan untuk mendidik yang memerlukan perenungan secara ilmiah. Kemudian Brodjonegoro S. mengadakan analisis terhadap istilah yang mengandung arti mendidik adalah sebagai berikut :

1. Paedagogiek atau teori pendidikan berasal dari kata Pais yang berarti anak, dan Agogos yang berarti penuntun, maka paedagogiek berarti ilmu yang menuntun anak.

2. Opvoeding (Belanda) pada permulaannya berarti membesarkan dengan makanan, jadi membesarkan dalam arti jasmaniah. Akan tetapi lambat laun tindakan membesarkan anak ini dikenakan juga pada pertumbuhan rohani anak. Juga pertumbuhan pikiran, perasaan kemauan dan watak anak.

3. Panggualwentah (Jawa) berarti mengolah, jadi mengolah kejiwaannya, ialah mematangkan perasaan, pikiran, kemauan dan watak sang anak.

4. Dalam bahasa latin terdiri dari dua kata, Educare dan Educere. Educare berarti merawat, memperlengkapi dengan gizi, agar sehat dan kuat, sedangkan Educere berarti membimbing keluar dari .... 5

Sehingga kita dapat merumuskan pengertiannya sebagai berikut: Pendidikan/mendidik adalah tuntunan kepada manusia yang belum dewasa untuk menyiapkan agar dapat memenuhi sendiri tugas hidupnya atau secara singkat pendidikan adalah tuntunan kepada pertumbuhan manusia mulai dari lahir sampai tercapainya kedewasaan, dalam arti jasmani dan rohani.

Menurut Samuel Sijabat: pendidikan adalah: Usaha orang dewasa dalam pergaulannya dengan anak untuk memimpin perkembangan jasmani dan rohaninya kearah kedewasaan. Atau jelasnya, pendidikan ialah pimpinan yang diberikan oleh orang dewasa kepada anak-anaknya, dalam pertumbuhan jasmani maupun rohaninya. Juga dapat berarti semua perbuatan dan usaha dari generasi tua untuk mengalihkan pengetahuannya , pengalamannya, kecakapannya, serta ketrampilannya kepada generasi muda sebagai usaha menyiapkannya agar dapat memenuhi fungsi hidupnya baik secara jasmani dan rohani. Selanjutnya ia lebih menekankan bahwa pendidikan adalah suatu proses perubahan sikap dan perilaku seseorang atau sekelompok orang dalam usaha mendewasakan manusia melalui upaya pengajaran dan pelatihan. ${ }^{6}$

\footnotetext{
${ }^{4}$ Suwarno, Pengantar Umum Pendidikan (Jakarta: PT. Rindu Cipta, 1992).10

${ }^{5}$ Brodjonegoro S, Pendidikan Nasional Indonesia (Yayasan Penerbit FIP IKIP, 1986).1

${ }^{6}$ Samuel B. Sijabat, Strategi Pendidikan Kristen (Yogyakarta: Andi Offset Yogyakarta, 1999).10
} 


\section{Teologia}

Telah terjadi beberapa perbedaan penulisan tentang istilah Theologi dengan menulisnya Teologi. Sebenarnya bila menyimak lebih dalam maka penulisan huruf Theologia itu lebih mendekati pada aslinya yaitu bahasa Yunani. Theologia berasal atau secara etimologisnya adalah dari kata Theos dan Logos. Namun akibat pengaruh bahasa Indonesia maka dewasa ini sudah dilazimkan kata theologi menggantikan Teologia, sehingga baik menggunakan Theologia maupun teologi akan tetap memberi arti yang sama.

Menurut KBBI edisi ke 3, Teologi adalah: pengetahuan Ketuhanan (mengenai sifat Allah, dasar kepercayaan kepada Allah dan Agama) terutama berdasarkan Kitab Suci. ${ }^{7}$

Menurut Henry C. Thiessen, teologi berasal dari Bahasa Yunani = Theos dan Logos. Theos berarti "Tuhan" dan Logos berarti "Kata", "Wejangan", atau "ajaran".Dalam arti yang sempit berarti study mengenai Allah. Dalam pengertian yang lebih luas, teologi adalah ilmu yang membicarakan tentang Allah dan alam semesta. Dengan penegasan bahwa teologi adalah suatu ilmu, ia hendak menekankan fakta bahwa Allah itu ada, dan Allah yang berada itu berhubungan dengan ciptaannya. Sebab seandainya tidak ada Allah, teologi tidak pernah ada. Demikian pula seandainya Allah yang berada itu tidak berhubungan dengan ciptaanNya teologi itu tidak pernah ada. ${ }^{8}$

Dengan pengertian ini, selain manusia dan alam yang menjadi objek penelitian, teologia terutama berupaya mengetahui tentang Allah walaupun Allah tidak dapat dipahami seluruhnya. Teologi yang sekalipun merupakan ilmu yang memiliki metode penyajian kebenaran yang luas tetap merupakan ilmu yang mutlak dan sekaligus relative. Teologi adalah ilmu yang positif namun terbatas maksudnya terbatas sejauh yang dinyatakan atau yang diajarkan oleh Alkitab. Positif dalam arti tidak dibangun atas rekaan yang irasional melainkan atas objek yang mengandung unsur pengetahuan yang benar dan nyata namun sering menemukan hal yang misteri.

Teologi mengetengahkan fakta-fakta kitab suci dalam urutan dan hubungan yang tepat dengan prinsip-prinsip atau kebenaran-kebenaran umum yang ada dalam fakta-fakta itu sendiri dan yang menyelaraskan seutuhnya. Selanjutnya Alkitab adalah sebagai salah satu sumber atau kategori fakta atau keberadaan yang tidak diwahyukan dimanapun juga. Sedangkan alam merupakan sumber atau kategori fakta lainnya yang makin diperjelas oleh Alkitab.

Jadi pendidikan Teologi adalah proses untuk mendewasakan seseorang tentang pengetahuan akan Allah, sehingga seseorang dapat berpikir atau berbicara tentang Allah melalui pengajaran.

Tujuan pendidikan teologi adalah untuk menjawab pertanyaan tentang kebenaran dan nilai yang mempengaruhi perseorangan dalam keseluruhannya sebagai sebagai satu pribadi. Kebenaran itu berhubungan dengan ada tidaknya transenden, sifat-sifatnya,

\footnotetext{
${ }^{7}$ Alwi, Kamus Besar Bahasa Indonesia. 1177

${ }^{8}$ Henry C. Thiessen, Teologi Sistematika (Malang: Gandum Mas, 1992).2
} 
kehidupan setelah kematian dan seterusnya. Tugas seorang teolog adalah mengajar, menganjurkan, menilai dan melibatkan diri untuk meneliti dan mengarahkan hubungan dan kegiatan antar manusia.

\section{Gembala Jemaat}

Istilah ini menunjukan pada jabatan dan tugas seorang pemimpin jemaat. Istilah ini memiliki sinonim seperti Pastor atau Pendeta. Menurut Poewadarminta W.J.S. istilah gembala memiliki pengertian sebagai berikut: a. Penjaga atau pemiara binatang (ternak). b. Penjaga keselamatan orang banyak. ${ }^{9}$

Alkitab adalah dasar pengertian ini dalam bahasa aslinya ditulis dengan istilah baru menggunakan bahasa Yunani. Di bawah ini akan dijelaskan pengertian istilah gembala dalam bahasa Ibrani dan Yunani.

\section{Pengertian dasar.}

Istilah gembala dalam bahasa Ibrani disebut $\boldsymbol{R} \boldsymbol{a a h}$, yang artinya memelihara suatu kawanan atau kelompok binatang. Seperti beberapa ayat dalam Perjanjian Lama yang menulis tentang istilah Gembala umpama Bilangan 27 : 17, "Yang mengepalai mereka waktu keluar masuk, supaya umat Tuhan jangan hendaknya seperti domba-domba yang tidak mempunyai gembala “. Pada ayat lain seperti Yehezkiel 34 : 11 - 12 : "Dengan sesungguhnya Aku sendiri akan memperhatikan domba-dombaKu seperti seorang gembala mencari dombanya pada waktu domba itu tercerai berai dari kawanan dombaNya".

Istilah gembala disini akan ditinjau dari penggunaan kata yang muncul di Alkitab. Kata gembala dalam bahasa Ibrani adalah Raah yang diterjemahkan dalam berbagai kata atau ungkapan yang memiliki hubungan dengan gembala, sedangkan dalam bahasa Yunani Poimen Kata raah muncul 167 kali dalam perjanjian lama, Istilah gembala diterjemahkan kedalam Bahasa Inggris dalam berbagai istilah antara lain " to tend a flock " yang artinya adalah memelihara suatu kawanan atau sekelompok binatang sejenis seperti dalam contoh menggembalakan ternak di padang rumput. Jika kata kerjanya berbentuk intransitive atau tanpa pelengkap penderita maka pengertiannya adalah mengiring atau merumput.

Gembala adalah seorang yang terus menerus berpartisipasi dalam memelihara ternaknya. Istilah ini biasa diterjemahkan dengan kata gembala misalnya dalam bilangan 27:17 yaitu yang mengepalai mereka waktu keluar dan masuk, supaya umat Tuhan jangan hendaknya seperti domba-domba yang itdak mempunya gembala. Kata mengepalai identik dengan tugas gembala. Kata "pemelihara ternak" dalam kejadian 46:34 adalah dari kata kerja "to rule" dalam bahasa Inggris yang mempunyai arti mengatur. Jadi gembala disini berarti kepala yang mengatur umat Tuhan, sedangkan dalam bilangan 27:16-17 istilah mengepalai bagi gembala digunakan istilah "to associate" yang artinya mempersatukan, dan banyak lagi ayat-ayat Alkitab yang menggambarkan tugas dan kegiatan gembala.

\footnotetext{
${ }^{9}$ Poewadarminta WJS, Kamus Umum Bahasa Indonesia (Jakarta: Balai Pustaka, 1983).311
} 
Konklusinya gembala itu dapat berarti :

1. Memberi keputusan atau mencari jalan keluar atau pemecahan suatu masalah (Problem Solving).

2. Mengiringai dan mengantar ke tempat yang aman.

3. Memberi arah pada sumber makanan dan minuman yang sesuai..

4. Menyuguhkan makanan yang segar dan menarik.

5. Memberi perlindugan yang bertanggung jawab.

6. Memperlakukan domba sebagai teman dalam hidupnya yang saling membutuhkan.

7. Sebagai pemelihara dan penjaga.

Dalam bahasa Yunani memberi pengertian agak berbeda dengan tiga istilah kata yaitu: Episkopos yang diterjemahkan kedalam bahasa Inggris sebagai Bishop atau Overseer. Presbuteros diterjemahkan Elder, sedangkan Poimen diterjemahkan Shepherd.

\section{Gembala Yang Berpendidikan Teologia.}

Dalam bagian kualifikasi Gembala Sidang telah dikemukakan Gembala haruslah orang yang cakap mengajar dan Efesus 4 : 11 menulis Karunia Gembala-Pengajar (PastorTeacher dalam bahasa Inggris atau Poimen-Didaskalos dalam bahasa Yunani) yang menggambarkan bahwa Gembala itu adalah pengajar atau guru.

Kalau tugas gembala itu guru maka lebih dari pengajar biasa tapi disebut cakap mengajar atau guru pada kategori pakar hampir sebagai ahli tapi bukan Maha Guru atau Profesor. Cakap mengajar bukan saja pada tingkatan memiliki licensi atau akta IV untuk ijin mengajar tapi dapat digolongkan M.Pd (Master Pendidikan) yaitu seorang yang dianggap mampu mengajar sesuai dengan syarat-syarat mengajar dan memiliki kompetensi mengajar.

Gembala yang disebut cakap mengajar tentu memiliki kapabilitas dan skill seorang guru. Bukan saja mampu mengajar tapi cakap mengajar dalam ukuran mampu terfokus pada pencapaian kompetensi jemaat yang diajar itu. Cakap mengajar (able to teach/apt to teach) adalah seorang yang memenuhi syarat guru yaitu minimal memiliki level satu tingkat diatas level yang ia pimpin. Syarat guru sekarang harus minimal memiliki ijazah S1, bagi tingkat sekolah dasar. Tentu saja bila mempelajari maksudnya maka seorang Gembala yang adalah Pastor Teacher haruslah seorang yang memiliki kurikulum, materi pelajaran, metode penyajian dan program evaluasi sehingga kegiatan belajar jemaat ini terencana, terarah, berjenjang dan memiliki tujuan dan hasil/effectivitas sehingga jemaat mengerti dan berubah, berkembang maju dan jemaat sebagai murid akan merasa segan, bangga dan puas serta mengakui pelayanan kita sebagai Pastor Teacher yang cakap mengajar.

Mengajar yang baik atau Pengajar yang qualified adalah seorang yang memiliki teori mengajar, didaktik metodik, applied, mampu menyusun program pengajaran, seperti 
contohnya mengacu pada kurikulum pendidikan yang disebut kurikulum tingkat satuan pendidikan (KTSP) yang memiliki 4 pilar yaitu :

- Belajar untuk mengetahui,

- Belajar untuk melakukan

- Belajar untuk menjadi diri sendiri

- Belajar untuk hidup bersama.

Seorang guru dituntut dapat menyusun syllabus, memiliki rencana mengajar, kurikulum berbasis kompetensi (KBK), kompetensi yang mencakup tiga aspek yaitu aspek coqnitif, affectif dan psikomotorik secara seimbang. Diharapkan dicapai pendekatan pembelajaran aktif untuk mencapai hasil belajar yang lebih optimal.

Dari persyaratan seorang Pastor Teacher yang mengutamakan metode mengajar yang baik dan memenuhi syarat, variatif dan kreatif akan mencapai hasil belajar yang berhasil guna dan berdaya guna.

Dari harapan yang diberikan kepada Pastor Teacher haruslah orang yang memiliki minimal tingkat S1 atau Sarjana Theologia. Sarjana Theologia adalah mereka yang telah memiliki mata kuliah minimal 70 mata kuliah dan itu diukur lengkap untuk tingkat dasar.

Dari seorang Pastor Teacher yang memiliki pendidikan Theologia S1 tersebut akan terlihat kemampuan menjawab tantangan kepemimpinan dan pendidikan sehingga yang bersangkutan mampu menjadi Pengajar, Pengayom, Pembimbing, sebagai Bapa atau ayah, konselor dan mumpu menyesuaikan dan menjawab tuntutan zaman, mampu mengimbangi dinamika ilmu pengetahuan dan technology dan dapat mengejar hal-hal yang baru atau kreatif, inovatif terutama dalam kaitan dengan penggembalaan.

Gembala yang berpendidikan Sarjana Theologia biasanya lebih cepat berinteraksi dengan ajaran-ajaran yang baru ditemukan oleh pada Sarjana dan mampu menerapkannya untuk dapat dicerna dan dipraktekan jemaat yang dipimpinnya. Gembala yang maju selalu beradaptasi dengan bahasa technology mengatur jemaat dengan situasi yang terkini atau kontemporer menerapkan konseling yang effective, menyusun job discruption yang systematis dan selalu dalam pengambilan keputusan (Decicion Making) telah melalui berbagai pertimbangan yang tentunya berakibat hal-hal yang menguntungkan.

Dari berbagai mata kuliah yang pernah diperoleh maka baik berkhotbah, baik memimpin, baik menerapkan organisasi dan kegiatan lain telah melalui pengkajian yang matang sehingga Pastor Teacher yang yang ditampilkan oleh yang bersangkutan mendekati memuaskan atau bahkan memuaskan ataupun perfectness.

\section{Bukti-bukti Gembala Yang Berpendidikan Teologia.}

Pada waktu Yesus memilih murid-muridnya maka selama pelayanan itu sekaligus Yesus mempersiapkan murid-muridnya untuk menjadi pemimpin. Murid-murid Yesus berguru kepada Yesus selama tiga tahun empat bulan atau selama 40 bulan yang waktu 
belajar sehari termasuk praktek adalah 10 - 12 jam. Jadi diperkirakan waktu mereka berjumlah 10 jam x 30 hari x 40 bulan yaitu mencapai 12.000 jam.

Bila kita melihat kurikulum yang diterapkan di Sekolah Tinggi yang penerapan akademiknya disiplin maka satu minggu 5 hari belajar dan 1 hari 6 jam sehingga seminggu 5 x 6 jam $=30$ jam yang sebulannya 30 jam x 4 minggu $=120$ jam. Jadi dalam 1 semester dibutuhkan waktu 4 bulan $\mathrm{x} 120$ jam $=480$ jam jadi bila kuliah S1 8 semester maka waktu yang ditempuh untuk meraih Sarjana Theologia adalah 8 semester x 480 jam = 3840 jam.

Untuk murid-murid yang belajar 12.000 jam berarti telah mencapai 3 kali lipat atau bila pencapain S1, 3840 jam, S2 3840 jam dan S 3 juga 3840 jam maka waktu yang dihabiskan hingga S3 adalah 11.520 jam masih waktu Yesus mendidik murid-muridnya lebih panjang. Katakanlah Petrus dan kawan-kawannya wajar kalau mendapat predikat S 3 atau Doktor.

Bila kita melihat pendidikan Paulus, ia kuliah di Universitas Tarsus dengan predikat S1 Sastra dan Sarjana Torat dibawah Pendidikan Prof. Gamaliel (KPR 22 :3) Dan untuk Kesarjanaan Theologia menurut Galatia 1 : 17-18, belajar selama 3 tahun. Kita melihat mereka baik murid-murid Yesus maupun Paulus semuanya mampu jadi pemimpin sesudah belajar dan bukti kepemimpinan mereka kesohor sampai keberbagai Negara seperti Italia, Asia, dan Negara-negara lain.

Jadi kita berkesimpulan bahwa ada sejumlah pemimpin yang dipersiapkan melalui pendidikan berjenjang yang sangat berhasil diteladankan oleh Yesus. Pada Perjanjian lamapun ada sekolah yang disiapkan untuk para calon pemimpin seperti II Raja 2 : 15 dan $6: 1$ - 7, ada sekolah di masa Elia dan Elisa. Jadi tidak benar teori bahwa nanti Roh Kudus yang mengajar dan tidak perlu sekolah.

Tidak sedikit waktu yang dibutuhkan untuk pemimpin sehingga pendidikan itu harus dijalankan dalam kurun waktu tertentu dan berjenjang. Selanjutnya mereka yang selesai pada S 1 waktu ditugaskan mengajar pelajaran agama di SD, SMP dan SMA tidak merasa sulit atau berat mengajar sebab mereka memiliki materi dan menguasai pelajaran itu secara lengkap untuk tingkat dasar.

\section{KESIMPULAN}

Ada sejumlah Tugas Gembala yang terlihat dalam gambaran Alkitab seperti ia harus merawat/membebati yang sakit/luka, memberi makan dan mengasuh, menjaga dan melindungi, mencari yang sesat/hilang, menjadi bapak/ayah, menjadi guru, rela berkorban / meniadakan kepentingan sendiri dan lain lain.

Dalam tugas membebati/merawat maka seorang gembala harus memiliki keahlian seperti seorang para medis atau dokter. Disini dituntut seorang gembala memiliki kemampuan professional dan sanggup merawat seperti layaknya sorang Dokter, dengan perkataan lain gembala harus seorang yang memiliki latar belakang pendidikan yang memadai sehingga mampu merawat dalam hal ini mengenal domba yang sakit dan terluka 
serta mampu memulihkan merawat/membebati sehingga domba mencapai tubuh yang sehat dan prima.

Memberi makan dan mengasuh adalah suatu pekerjaan dari seorang yang memiliki kemampuan seperti seorang Sarjana Kesehatan ahli Gizi yang bukan saja dapat menyeleksi makanan yang sehat dan bergizi juga memberi makanan dengan teory yang benar sehingga domba sehat, kuat dan memiliki daya tahan juga dapat memberi susu serta daging yang gemuk untuk tuannya.

Dikaitkan dengan keahlian dalam tugas maka seorang gembala haruslah orang yang memiliki pengetahuan dalam memberi makan dan mengasuh domba bukan bekerja asal jadi tapi harus diperhitungkan dengan baik.

Menuntun dan membimbing adalah suatu kemampuan seperti seorang guide yang menguasai medan dan situasi tempat dimana domba akan dibawa. Seperti membawa ke air yang tenang jangan keair yang berbahaya atau menghanyutkan sehingga domba terancam.

Selain itu Membimbing juga ke padang rumput harus diperhitungkan daerah yang sesuai dari kebutuhan makanan jangan berjurang/curam dan letak yang berbahaya.

Menjaga dan melindungi adalah suatu tuntutan bagi seorang gembala yang memiliki keberanian, ketrampilan menghadapi binatang buas dan menyediakan tempat perlindungan pada waktu domba istirahat apalagi berteduh atau tidur waktu malam. Gembala dalam hal ini selalu berjaga dan awas terhadap binantang buas dan harus memiliki kemampuan seperti Daud.

Jadi gembala dalam kaitan dengan menjaga dan melindungi adalah suatu kemampuan/ketrampilan untuk berperang jadi harus berani dan trampil. Dari kesimpulan diatas seorang gembala haruslah seorang yeng memiliki latar belakang pendidikan, ketrampilan dan professional atau haruslah seorang yang Sarjana sehingga dapat menjawab profesionalisme Gembala. Seorang Gembala adalah seorang yang memiliki kriteria atau kualifikasi Pribadi, keluarga, public dan pelayanan sehingga seorang gembala sidang haruslah orang yang memiliki dan memenuhi kriteria tersebut sehingga tututan bagi seorang gembala yang berpendidikan sudah sangat mendesak dan merupakan suatu keharusan.

\section{KEPUSTAKAAN}

Alwi, Hasan. Kamus Besar Bahasa Indonesia. Jakarta: Balai Pustaka, 2005.

S, Brodjonegoro. Pendidikan Nasional Indonesia. Yayasan Penerbit FIP IKIP, 1986.

Sijabat, Samuel B. Strategi Pendidikan Kristen. Yogyakarta: Andi Offset Yogyakarta, 1999. Simanjuntak, Fredy. "Kecerdasan Emosi Pemimpin Sebagai Tolok Ukur Gereja Yang

Sehat." Real Didache 2, no. 1 (2017): 29-53.

Suwarno. Pengantar Umum Pendidikan. Jakarta: PT. Rindu Cipta, 1992.

Thiessen, Henry C. Teologi Sistematika. Malang: Gandum Mas, 1992.

Tidball, Derek J. Teologi Penggembalaan Sebuah Pengantar. Malang: Gandum Mas, 1986. WJS, Poewadarminta. Kamus Umum Bahasa Indonesia. Jakarta: Balai Pustaka, 1983. 